UDC 378.811 .111

\title{
COMMUNICATIVE APPROACH TO TEACHING ENGLISH AT TECHNICAL UNIVERSITIES
}

\author{
M. V. Shevchenko \\ Kyiv, National Technical University of Ukraine \\ "Kyiv Polytechnic Institute" \\ marianashevchenko@ukr.net
}

The article deals with the communicative approach to teaching English at technical universities. The constituents of the communicative competence are presented. Differentiation between two ways (strong and weak versions) of development of students' communicative abilities can also be found in the proposed paper. The distinction lies in variance of ways of the English language acquisition by students, including those of technical specialities. The work contains lists of peculiarities of explicit/implicit learning and teaching with the help of communicative language teaching (CLT). Their positive sides and weaknesses are considered. Three central areas of explicitimplicit teaching - focus on form and form-focused instruction, fluency and automation, formulaic language - are also reviewed. The main attention of the article is paid to the aim, key characteristics and principles of the approach in question, as well as to advantages and disadvantages of the communicative approach use at the English language lessons. Among quality assessment criteria of the communicative teaching are efficiency of the English language acquisition, novelty of materials, and also effectiveness of educators' and students' work. Recommendations for teachers, concerning the proper CLT implementation at the lessons of English for Specific Purposes, and features of recommended classroom activities to do so are provided at the end of the article.

Key words: communicative approach, CLT, the English language, technical universities, principles, explicit and implicit learning, communicative competence.

Introduction. An issue of students' communicative competence development is becoming more and more significant at universities every year, as long as international cooperation in all spheres is viewed as the crucial element for the status of any country and its representatives around the world. As current students are the future "driving force" of the progress, it is essential to prepare them for this mission now. Therefore, replacing traditional teaching approaches with more innovative and efficient ones is the most important task in education at present. This change can only be done using the communicative approach to teaching English, especially at technical universities.

Aim and tasks. The goal of this paper is to examine features of the communicative approach to teaching English at technical universities. The tasks of the research are to: determine the notion and the aim of the communicative approach, outline its main characteristics and principles, enumerate advantages and disadvantages of the CLT implementation, and provide recommendations for the English language teachers of the approach mentioned in the article's name.

Background. As has been mentioned, the communicative approach to teaching English is of current importance, so many scholars investigate various aspects of it. Among them are K. Brandl [2], M. Canale and M. Swain [3], Z. Dörnyei [4], T.V. Hattum [7], B.B.N. Prasad [9], S.J. Savignon [11], M. Tsinghong [12], and many others, who devoted their works to relevant innovations, concerning development of students' communicative skills with the help of CLT, although the 
issue of its use at higher technical educational establishments still remains an active area of pedagogical research.

Research. The communicative approach to teaching the English language was presented in the 1970s by British and American scholars in order to increase the effectiveness of communicative skills development of non-native English speakers [4, p. 162]. Often the above-stated approach is called "CLT" (communicative language teaching) or "communicative approach".

The foremost purpose of the CLT is to develop students' communicative competence with the help of building the educational process around interaction in the foreign language, so that in perspective they could converse well and appropriately [12, p. 42].

CLT develops students' communicative abilities either by teaching aspects of communicative competence, i.e. realization of specific general notions (the weak version), or by creating conditions for learners to acquire the foreign language through communicating (the strong version) [6, p. 340]. The later variant incorporates an idea that students actually discover the structural system of language as itself in the process of learning how to communicate, therefore they are provided with opportunities to experience how language is actually used in communication and activate the inert knowledge of the language system [10, p. 155].

Communicative competence comprises [3; 9, p. 2-3]:

- Grammatical competence (the main goal is not to demonstrate the knowledge of grammar rules but a grammatical competence - using a rule in the negotiation of meaning, expression or interpretation);

- Discourse competence (understanding the nature of correlation between certain words or phrases in a text, and the ability to interpret the overall meaning of the text properly);

- Sociolinguistic competence (comprehension of the social context in which language is used);

- Strategic competence.

There are two types of language learning: implicit and explicit.

1. Explicit learning constitutes a conscious and deliberate endeavour to master some material. This learning type is peculiar to most school instructions.

2. Implicit learning is getting more and more popularity at the English lessons, turning them into communicative ones. The basis of this type is the maximal approximation of a natural language acquisition environment, crucial element of which is provision of abundant authentic materials for students in order to facilitate their implicit learning processes. The foundations of the discussed learning type can also be found in the process of our mother tongue mastering, which mainly incorporates implicit operations without any explicit teaching: children acquire the L1's (native language's) complex system via participating in natural and meaningful communication with people close to them. This is the core language learning model for humans [4, p. 163].

Still, there is an argument concerning a certain weakness of the implicit learning. Professors P.M. Lightbown and N. Spada [8, p. 176] have made a conclusion that there is no indisputable confirmation of the hypothesis that language 
acquisition will take place without any problems if second language learners, including students of technical universities, simply focus on meaning in understandable input. That is to say, a mere exposure to L2 (non-native/second language's) input and its combination with communicative practice are not enough, and such explicit learning processes as focus on form or some kind of controlled practice are necessary. Thus, the real challenge is to maximize the cooperation of explicit and implicit learning [4, p. 164].

Modes of the explicit-implicit teaching take place in three central areas [4, p. 165-168]:

1) focus on form and form-focused instruction (the primary attention is focused on meaning-oriented approach, as well as the L2's formal/structural aspects, which define accuracy and relevance);

2) fluency and automation (L2 fluency is as essential as the correct use of linguistic form as far as the communicative efficiency is concerned);

3) formulaic language (every person, who studies English, should accumulate knowledge of thousands or tens of thousands of language units, selected phrases, continuously and rigorously practice their use in speech and writing). It is vital to remember that the formulaic language competence is directly linked to fluent and automatized language production.

Such scholars as B.B.N. Prasad [9, p. 2, 4-5], K. Brandl [2, p. 7], C.J. Doughty and M.H. Long [5, p. 58], J.C. Richards and T. Rodgers [10], and others give the following characteristics of CLT:

- Teaching is student-centred; it takes into account their language needs and interests, goals concerning a future profession, and altogether allows learners some resourcefulness. At the same time, language teaching is no longer a one-way transmission of knowledge from teachers to students, now they both are working together - cooperation is the core of CLT.

- The teacher in the language classroom is a facilitator, who creates a climate stimulating studying with opportunities for students to practice English.

- The negotiation of meaning, information exchange, choice-making and problems solving create interaction at the lesson, what, in its turn, contributes to the target language (TL) acquisition. A vivid example can be given with the help of the following comparison: the attraction of a football game lies not in the football itself, but in the players' moves and strategies; the same is with communication - the steps and strategies of the participants are the ones in the limelight $[9$, p. 2]. Moreover, the wider the variety of communicative, or meaning-based, activities, the greater the chance of involving all students, the leaders and the followers, who are equally essential for the group activities' success.

- There is an abundant exposure to the authentic language. Examples are found in the TL community, and are represented by non-pedagogic materials, thus, students' communication activities are connected to real-life contexts and situations. As C.J. Doughty and M.H. Long [5, p. 58] stated, new knowledge is integrated into the long-term memory more effectively and can be retrieved easier, if it is linked to real-world events and actions.

- The study of language formal properties is never segregated from its use; there is always a strong interdependence between forms and a communicative context. 
- Language forms and structures are discovered by students without assistance.

- The four language skills - listening, reading, speaking, writing - are incorporated, creating a whole-language approach.

From the aforecited features of CLT, its principles ensue [1, p. 259; 2, p. 12$21 ; 12$, p. 44-45]:

1. Concentration on communication.

2. Learning by doing is promoted.

3. Reflecting a real communicating process.

4. Rich input. One of the biggest necessities in teaching is to make sure students are exposed as much as possible to the authentic language discourse, for instance, it is supremely important to utilize original multimedia resources to the maximum (DVD-, TV-recordings, video and audio materials taken from online- or radio sources, etc.).

The English authentic materials expose students to the real and up-to-date language, in contrast to the artificial, i.e. pedagogical, contain contexts in which it naturally occurs, and thus, produce a more creative approach to teaching $[2$, p. $13 ; 10]$.

5. Input should be meaningful, comprehensible, and elaborated. The obtained educational information must be clearly relevant to the professional knowledge that students already possess, while input cannot be meaningful unless it is comprehensible.

6. Co-operative and collaborative learning is promoted. Students are active participants in the joint work on an assigned language-learning task, utilizing only the target language for communicative purposes, and, in the course of interaction, negotiating the type of input they receive.

7. Focus on form. According to S.J. Savignon [11, p. 7], to develop communicative skills, an integration of form-focused exercises with meaning-focused experience should be present in the teaching process.

8. Provision of positive or negative mistakes-corrective feedback.

9. Affective learning factors are recognized and respected. A motivated student wants to achieve a certain aim, does plenty of activities and devotes a lot of effort to do that. People, who are studying, for example, English for Specific Purposes, should not be defensive or feel anxious at the lesson but, on the contrary, be encouraged to gain some new knowledge or discuss the received information.

Although, there are plenty of advantages of the teaching approach in question, problems with its use still exist. Namely, the communicative approach to language teaching, especially at technical specialities at universities, often tends to be interpreted as: if the teacher understands the student, the communication is acceptable. The difficulty lies in that this teacher, in most of the cases, is also a speaker of student's L1 and so understands the student even with his/her mistakes, resulting from the influence of the first language. But native speakers of the studied language do not have the same way of thinking, hence can easily and completely misunderstand, what has been said by that non-native speaker. This observation needs rethinking and adjustment of the CLT. The altered communicative approach will only be efficient, when the teacher pretends to comprehend only that what any regular speaker of the target language would, and should react in accordance [7, p. 10]. 
In order to achieve positive results with teaching students of technical specialities, certain precise recommendations of the proper CLT implementation at the lessons of English for Specific Purposes should be given. Among them are to [2, p. 14-16]:

1. Use the target language at the maximum during instructions giving. The more students hear the TL, the better, since the larger the studied language input, the greater the students' advances.

2. Serve as an example to your students of a proper, high-class foreign language use. Never switch back and forth between the TL and the learners' native language. Do not expect students to use the English language, or any other non-L1, if you, as their mentor, cannot use it consistently yourself.

3. Motivate students; give multiple arguments for using the TL at present and in time to come, i.e. in their future profession.

4. Give clear instructions.

5. Develop four traditional skills - listening, reading, speaking, and writing in correlation.

6. Organize maximum interaction between people, who are studying English. Active academic work at the foreign language lessons affects positively on students [1, p. 257]. Cooperation "students-learning materials-other students- the teacher" is imperative for the ultimate result of the target language acquisition.

Considering the above-mentioned recommendations, classroom activities typically should have at least some of the following distinctive features [9, p. 5-6]:

- Enhancement of students' communicative competence through combination of grammatical knowledge and communicating ability. Grammar rules are not taught separately but quite the contrary - arising out of a communicative assignment, and so producing a necessity for particular elements of grammar.

- Stimulation for intercourse and discussion with the help of such tasks as a role play, problem solving, or information sharing.

- Providing opportunities for both inductive and deductive study of grammar.

- Incorporation of educational materials, which would include content related to students' interests - both in (future) professional sphere and personal.

- Usage of authentic materials (audiovisual or written) to stimulate attention and provide models of the real, "living", target language, for instance English. This is imperative in the process of English for Specific Purposes acquisition.

Conclusion. To sum up the foregoing information on the communicative approach to language teaching at technical universities, it must be pointed out that among advantages may be: 1) faster and more efficient results (in comparison to the traditional methods and approaches) of the foreign language acquisition by students due to the use of communicative tasks, 2) bigger involvement of students in the studying process (student-centring), and therefore their higher responsibility for the achievement of the lesson's goal, 3) contextualization of the educational information, including lexis and grammar, for better understanding of meaning, 4) indissoluble connection between the real-life language and situations of its use, and the ones presented and studied at the English language lessons, concerning everyday life, as well as students' (future) professional field. Disadvantages may be represented by the following situations: 1) possible prioritizing of fluency over accuracy, 2) lack of 
authentic materials, representing native speakers' 'living' language, and equipment for their demonstration, 3) impossibility of implementation of the teaching approach in question fully due to large sizes of academic groups, 4) low-quality professionalism of teachers resulting in ineffective organization of teaching process.

Teachers' awareness of such problems with CLT can help them improve their teaching approach and avoid such disadvantages at their English lessons in future, especially ones conducted for students of technical specialities. Hopefully, the numerous features of the communicative approach to language teaching will be helpful for foreign language teachers, and the recommendations for the use of the approach in question will stimulate continuous upgrading of their professionalism, advanced training, and unstoppable search for and implementation of the most up-to-date, interesting and motivating authentic materials, desirably audiovisual, relevant to students' target language knowledge level, as well as their personal and professional interests and needs. This remains invariably vital in the educational sphere from year to year.

\section{REFERENCES}

1. Agbatogun, A. O. (2014). Developing Learners' Second Language Communicative Competence through Active Learning: Clickers or Communicative Approach? Educational Technology \& Society, 17 (2), 257-269.

2. Brandl, K. (2007). Communicative Language Teaching in Action: Putting Principles to Work. Upper Saddle River, NJ: Prentice Hall. 464.

3. Canale, M. and Swain, M. (1980). Theoretical bases of Communicative Approaches to Second Language Teaching and Testing. Applied Linguistics, 1 (1). 1-47.

4. Dörnyei, Z. (2013). Communicative Language Teaching in the Twenty-First Century: The 'Principled Communicative Approach'. In J. Arnold \& T. Murphey (Eds.), Meaningful Action: Earl Stevick's Influence on Language Teaching. Cambridge: Cambridge University Press. 161-171.

5. Doughty, C. J. and Long, M. H. (2003). The Handbook of Second Language Acquisition. Oxford: Blackwell.

6. Ellis, R. (2003). Task-Based Language Learning and Teaching. Oxford: Oxford University Press.

7. Hattum, T. V. (2006). The Communicative Approach Rethought. Retrieved from: http://www.tonvanhattum.com.br/comreth.html. Last accessed 14th March 2015.

8. Lightbown, P. M. \& Spada, N. (2006). How Languages are Learned. $3^{\text {rd }}$ ed. Oxford: Oxford University Press.

9. Prasad, B. B. N. (2013). Communicative Language Teaching in 21st Century ESL Classroom. English for Specific Purposes World. 14 (40). Retrieved from: http://www.esp-world.info/. Last accessed 14th March 2015.

10. Richards, J. C. \& Rodgers, T. (2001). Approaches and Methods in Language Teaching. $2^{\text {nd }}$ ed. New York: Cambridge University Press.

11. Savignon, S. J. (2002). Interpreting Communicative Language Teaching: Contexts and Concerns in Teacher Education. New Haven, CT: Yale University Press.

12. Tsinghong, M. (2009). On Communicative Language Teaching Theoretical Foundations and Principles. Asian Social Science. 5 (4). 40-45. 
М. В. Шевченко. Комунікативний підхід до навчання англійської мови в технічних університетах.

Стаття присвячена комунікативному підходу до навчання англійської мови в технічних вищих навчальних закладах. У цій праці представлені складові комунікативної компетентності. Також розглядається диференціація між двома способами розвитку комунікативної компетентності студентів - сильним і слабким. Робота містить списки особливостей експліцитного й імпліцитного навчання та викладання за допомогою комунікативного підходу, або, як його ще називають, комунікативного навчання мови (англ. назва - "communicative language teaching", CLT). Аналізуються їх позитивні та слабкі сторони. Головна увага приділяється меті, основним характеристикам і принципам підходу, зазначеного в темі статті, включаючи переваги й недоліки використання комунікативного підходу на заняттях із англійської мови в технічних ВНЗ. Критеріями оцінювання якості комунікативного навчання $€$ ефективність набуття знань із англійської мови, новизна матеріалів, а також результативність роботи педагогів і студентів на заняттях. Наприкінці наводяться рекомендації для викладачів, що стосуються належного впровадження та використання CLT (комунікативного навчання мови) на заняттях англійської мови в технічних університетах, а значить для навчання студентів немовних спеціальностей, включаючи рекомендовані види роботи в аудиторії для виконання вищевказаної задачі.

Ключові слова: комунікативний підхід, CLT, англійська мова, технічні університети, принципи, експліцитне й імпліцитне навчання, комунікативна компетентність.

\section{М. В. Шевченко. Коммуникативный подход к обучению английскому языку в технических университетах. \\ Статья посвящена коммуникативному подходу к обучению английскому языку в} технических ВУЗах. В данном материале представлены составляющие коммуникативной компетентности. Также рассматривается дифференциация между двумя способами развития коммуникативной компетентности студентов - сильным и слабым. Работа содержит списки особенностей эксплицитного, а также имплицитного обучения и преподавания с помощью коммуникативного подхода, или, как его еще называют, коммуникативного обучения языку (англ. название - “communicative language teaching", CLT). Анализируются их положительные и слабые стороны. Существенное внимание уделяется цели, основным характеристикам и принципам подхода, указанного в теме статьи, включая преимущества и недостатки использования коммуникативного подхода на занятиях по английскому языку в технических высших учебных заведениях. Критериями оценивания качества коммуникативного обучения являются эффективность приобретения знаний по английскому языку, новизна материалов, а также результативность работы педагогов и студентов на занятиях. В конце приводятся рекомендации для преподавателей, касающиеся надлежащего внедрения и использования CLT (коммуникативного обучения языку) на занятиях английского языка в технических университетах, а значит для обучения студентов неязычных специальностей, включая рекомендованные виды работы в аудитории для выполнения вышеуказанной задачи.

Ключевые слова: коммуникативный подход, CLT, английский язык, технические университеты, принципы, эксплицитное и имплицитное обучение, коммуникативная компетентность. 